\begin{tabular}{cc}
\hline International Journal of Engineering \& Technology, $7(4.34)(2018) 41-47$ \\
SPC \\
Sernational Journal of Engineering \& Technology \\
Website $w w w . s c i e n c e p u b c o . c o m / i n d e x . p h p / I J E T$ \\
Research paper
\end{tabular}

\title{
A Sociocultural Theory to Learning: Malaysia's Experience
}

\author{
Norsuhaily Abu Bakar*, Ahmad Puad Mat Som \\ Faculty of Applied Social Sciences, Universiti Sultan Zainal Abidin, Terengganu, Malaysia \\ *Corresponding author E-mail: norsuhaily@unisza.edu.my
}

\begin{abstract}
The study explores and analyses some of the challenges inherent to incorporating play into classroom practice, which occurs in two types of preschool classroom settings in Malaysia. It investigates the implementation of play in each of these settings. This study builds an understanding of the processes involved. It demonstrates a theory of learning that supports analysis of participation in social activity where participants work towards social goals within a view of learning being based on a cultural and collective foundation. The discussion is designed to convince the reader the value of the underpinning theory for this study and to explain the interpretive lens on learning through play that emerges. The approach recognizes that this interpretive lens offers a particular way of guiding the data collection and interpreting the data. In developing a conceptual framework for this study, it provides not only a way to interpret what is learning through play, but also to report the research findings within a sociocultural frame.
\end{abstract}

Keywords: Sociocultural theory of learning; Interpretive Lens; Vygotsky; Play; Children.

\section{Introduction}

This study explores the theory of the main contributor to sociocultural thinking, Lev Vygotsky (1896-1934). The theory, discussed here to demonstrate Vygotsky's sociocultural theory and to provide a succinct account of how it fits with the early childhood sector. The Vygotskian concept of "internalized" knowledge [1] integrates the inter-mental and intramental processes on the interactive plane.

This theoretical development proposes that learning is always intermental, that is, constructed between people. What appears as an intramental process, that is, an internal, individual construction is part of an ongoing social conversation. Post-Vygotskian educationalists, in [7-8] with the psychologist, [20] and the sociologist [4] contribute to formulate a theory of learning that proposes that individuals are never separate from the social, that humans are primarily driven by a need to be part of a community, to share thinking with others and that from the beginning of life children are proactively engaged in meaning-making towards the cultural goals of their communities [6].

In this context, it is valuable to refer to [2] who describes culture as the "implicit semi-connected knowledge of the world, from which through negotiation, people arrive at satisfactory ways of acting in given contexts". For [2], intersubjectivity is the neglected or "impoverished" strand of sociocultural theory. According to [3], "the theory proposes that in their intersubjective (shared understanding) interactions with others, children are learning and contributing to the ways of communicating, thinking and knowing in their communities". In [4] goes on to say that "these intersubjective communications with others are socially distributed across or mediated by cultural histories, places, people and things", and are situated in "communities of practices" [3]. Learning then is a process of "transformation of participation" [5]. In the process of "participation both context and participants are transformed in ways that prepare them for future participation" [6].

This sociocultural theory of learning leads to interpersonal meaning making, including learning through play while children interact with each other. This discussion demonstrates why this study has adopted a sociocultural perspective. It is an investigation into how teachers implement learning through play in classroom practices. The interview and observation lenses used in the study focus attention on how teachers reconstruct the activities planned and children's practices that are framed in play. And uses the work by [7], who identifies the "key concepts that are vital to this understanding of learning. These are: (i) learning is mediated by social context; (ii) it happens through intersubjective processes in interactive social activity with other community members; and (iii) it leads to "transformation of participation".

\section{Vygotsky's Sociocultural Theory}

Sociocultural theory is strongly associated with the writing of the Russian educational theorist Lev Vygotsky [5, 8] and Dewey, who in the first half of the 1900's was thinking along similar lines, indeed Dewey and Vygostky shared communications that demonstrated similar lines of thought.

It begins with an exploration of the role of culture in learning and in the children's development. As discussed, for [9] the ZPD is a key part of that development and so a discussion on the ZPD precedes exploration of the impact of Vygotsky's theory on our understanding of learning and the practice of education. This is followed by an analysis of Vygotsky's [9] theory on children's play. The section concludes by integrating his broader sociocultural and play theory to determine Vygotsky's contribution to our understanding of play.

Vygotsky's theory of cognitive development is very important to this study. It: 
... priorities learning on the intermental plane and stresses that individual intelligence develops as a result of the biological person actively participating in a physical and particularly a social environment with other people towards community goals. It proposes that the formation of mind is inextricably linked to the historical and cultural context [10].

In [11] discussed that, children develop within a cultural matrix, two key interconnecting elements: a system of social relationships and the cultural conceptual and symbolic system. We see that within social activity, a child appropriates the cultural resources accumulated by his/her society, including a language, cognitive frameworks, cultural artifacts and a bank of knowledge. "The special quality of the human environment is that it is suffused with the achievements of prior generations in reified (and to this extent materialised) form" [10]. Children are equipped to interpret future experiences. Vygotsky's theory demonstrates how children, through interactive guidance of those more capable can learn to participate and develop into the adult culture of their communities $[5,8]$.

In [9] wrote that culture only alters natural data in conformity with cultural goals. This of course gives rise to the possibility of major differences in developmental paths of those from different cultural milieu. In [9] separates development and learning in the young child with his concept of the ZPD theory.

The zone of proximal development is the distance between the actual developmental level as determined by independent problem solving and the level of potential development as determined through problem solving under adult guidance or in collaboration with more capable peers [9].

According to Vygotsky learning occurs in the ZPD. It therefore offers a crucial role for the adults or "expert others", in progressing learners [12]. This concept encourages us to consider that children develop through being guided by the values, goals and activities of the people with whom they live. This concept situates learning within participation in community activity and suggests that we need to consider the context and process around a learner if we are to understand their development. The concept of the ZPD, encourages us think about educational practice in new ways, indeed it is the key concept, in describing structured teaching and learning situations.

Vygotsky specifically links play with learning. He believes that peers offer each other guidance as play itself creates the ZPD. Because "in play the child is always above his average age, above his daily behaviour; in play it is though he were a head taller than himself" [9]. This statement reflects Vygotsky's particular valuing of representational learning which is he suggests best practiced in sociodramatic and imaginary play. This position of ZPD status, valuing play among peers, highlights the significance of the role of play in the education of the child. For Vygotsky:

Children learn to create, master and give meaning to signs and symbols through play. They go beyond recollection and imitation and reconstruct implicit social rules for their own play purposes. Play is therefore both a medium and context to negotiate and exercise children's understanding of cultural relationships, roles and practices. For Vygotsky, play is always a social, symbolic activity, even when children play alone, because, in play, he postulates children are representing and developing their understandings of cultural experiences [9].

The motivational basis of play, according to [9] is firstly emotional. He cites imaginary play, as the child's way of realising, needs, roles and skills that otherwise cannot be realised in ordinary life "To resolve this tension, the preschool child enters an imaginary, illusory world in which the unrealisable desires can be realised, and this world is what we call play". In [9] defines two types of rules in play that lead to "moral realism": rules imposed by adults and rules of self-restraint constructed by children. He describes how children voluntarily submit to the rules of pretend roles, that they show self-restraint and adhere to the rules of the situation. $\mathrm{He}$ further argues that children demonstrate their understanding that roles and contexts frame and are framed by rules of behaviour. According to Vygotsky:

... in imaginary play the imaginary element is explicit and the rules are implicit. In structured play, the imaginary element is implicit and the rules are explicit. Therefore, play offers possibilities for an investigation of the rules of social behavior and consequently provides a route to understanding children's interpretations of the rules of real life.

According to [9], emotion is the primary motivation for play as it enables the child to realize wishes and to trial skills.

To resolve this tension, the preschool child enters an imaginary, illusory world in which the unrealizable desires can be realized and this world is what we call play [9].

Through imaginary play, children voluntarily submit to social rules. Children play pretend, which allows them to suspend reality. "Thus, children learn through play that achieving their own desires requires voluntary obedience to self-chosen rules and that their individual satisfaction can be enhanced by cooperation in rulegoverned activities" [11]. Through this process, rules become internalized.

\section{From Sociocultural Theory to Practice}

Knowledge is co-constructed with others as children participate in their social and cultural worlds as active agents who play decisive roles in determining the dynamics of social life and in shaping individual activities [13]. Ways of knowing and participating emerge in different sociocultural practices, which embody the beliefs, rules, patterns of behavior, language and interaction, routines and expectations within communities. For example, children do not just learn isolated skills (such as decoding words, practicing handwriting or recognizing numerals); they become, for example, readers, writers, communicators and mathematicians through sustained engagement in practice, which can be adult- or child-initiated. This focus enables us to identify teaching and learning activities within the sociocultural tradition, and offers a way of concretizing the theory and identifying practical strategies to analyse the implementation of play activities.

Once we shift the focus from individual development to the social characteristics of play, we provoke critical consideration of agency, power and control in adult-and child-initiated activities [14].

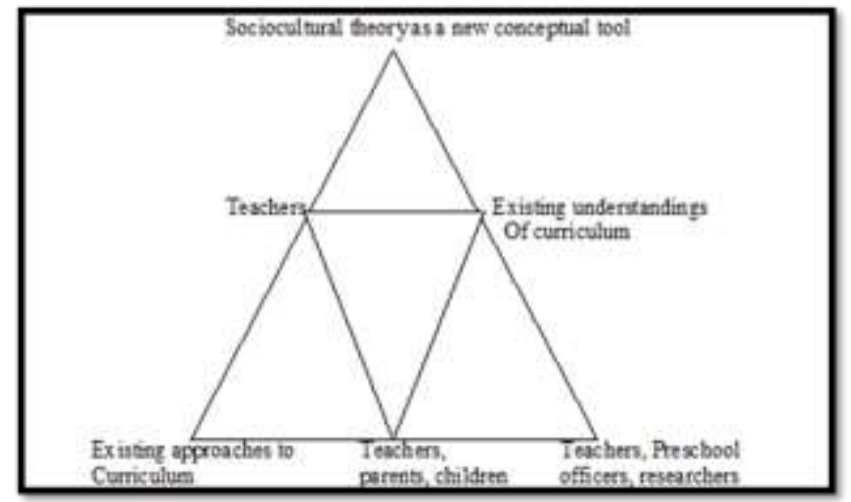

Fig. 1: Sociocultural theory as a lens for challenging teachers' existing understandings of curriculum [15]

Fig. 1 is introduced here as it provides a model that uses sociocultural theory to challenge teachers' understandings of curriculum and a framework to generate reflective practice on the use of sociocultural theory in early childhood education. In considering the model, we can see that a sociocultural lens enables us to consider 
what is occurring in a classroom from a new angle. We are also able to see that the improvisational and spontaneous nature of play makes particular demands on children's imaginative and relational capabilities, for example any play activity (particularly role play or imaginative play) is not one event, but many other different types of events [13].

\section{Scaffolding}

According to $[16,17]$ determined the notion of 'scaffolding' to describe the learning support process in the ZPD. In [16] regards scaffolding as the process of a teacher organizing a task so as to bring it within the child's "region of sensitivity" to instruction. A teacher needs to be alert to the cues from a student and be ready to help as needed. A teacher's aim is to transfer control to the learner as the learner's capacity increases. In elaborating further on the concept of scaffolding, [18] "emphasizes the two rules of "contingent' support. "The first rule dictates that when a child fails to achieve after one level of support is offered, then the support is immediately increased. The second dictates that when a child succeeds, the level of support should decrease".

In [18] considers that the highest levels of control relate to modeling as a support. In [19] continue this discussion by drawing attention to the lower level supports, which Wood describes as involving verbal instruction belonging in communities where children are segregated from adults' work. For this study, it is important to be clear that I also see scaffolding and contingency as culturally defined concepts with ways of learning embedded in context.

'Scaffolding' is about assisting and supporting learners and by focusing on learning through play this study enables us to focus on emergent thinking as participants guide one another's contribution through self-other regulation and contingent responses. We now arrive at a discussion on the idea of 'guided participation'. This idea is particularly pertinent to early childhood education. In the Malaysian context particularly, from my own observation, over time, behaviorist theory and teacher-centred pedagogy have strongly influenced teachers' understandings of curriculum and pedagogy.

This discussion has focused attention on Vygotsky's principal contributions to our understanding of play. We have considered the sociocultural theory underpinning the study, and demonstrated how the focus of Vygotsky's research was on the means, the functions and the processes of participating within a social and cultural system [6, 20]. The value of Vygotsky's theory as a framework explored as means to guide the investigation and to provide a lens to analyze challenges inherent in incorporating play into classroom practice. This unique opportunity to interpret results from a new vantage point has potential to add innovative and original insights to current data on the importance of learning through play. The contexts under study here are four different types of preschool classroom settings in Malaysia.

\section{Methodology}

\subsection{Observations}

The researcher spent two weeks in one of Malaysian preschool in order to trial and refine the observation instruments. One week was spent in observing classroom activity and consulting with teachers. The second week allowed me to trial the modified instruments. The preschool was chosen because it was in a convenient location for me to visit, this being the only consideration in choice of school. I was unknown to the administrator/headmaster, teachers and children and believed this to be very important for trial procedures planned for the major study, as this would also be the case in the major study. The administrator/headmaster welcomed me to the preschool and expressed a keen interest in learning through play approach. Initially, I spent two and a half weeks in the preschool classroom after looking at the teacher's lesson plans. While, there I had a formal discussion with the preschool teachers and a lecturer from the Teacher Training Institute who was majoring in Early Childhood Preschool Education and doing her practicum observation of the teacher trainers there. This opportunity assisted me in deciding how to efficiently divide play activities into types of play for observation purposes. I decided on how to divide the play activities after observing teaching and learning practices and by considering their lesson plans.

My observations and the trial of instruments developed for the types of play spanned two weeks for four to five hours a day, according to the schedule and lesson plans of the teachers. Detailed notes of the play observed encouraged consideration of emerging types of play, which confirmed my predictions in a general sense about what types of play I would observe in preschool practices. I observed children involved in riddles, chants and rhymes activities, role play/imaginary play, creativity/ scientific play activities, physical play, structured play and free play. Throughout the observation in the pilot study of each category types of play, I also found that children shared an understanding of roles and relationships, engagement in the activity, the usage of play equipment and adults' guidance in certain situation of play occurred.

The important outcomes of the pilot study were: confirmation and refinement of a typology of play for use in the larger study; the identification of teaching styles of the preschool teachers; engagement in play activities; and refinements to the interview questions. This pilot ensured the best possible instruments for use in the main study. I trialed the typology of play and found that the following list most adequately described observations of children at play: riddles, chants and rhymes activities, role play/imaginary play, creativity/ scientific play activities, physical play, structured play and free play. The types of play are based on the work of other researchers and theorists [21-26] as discussed in chapter three.

\subsection{Data Analysis}

In [27] define qualitative data analysis as "working with data, organizing it, breaking it into manageable units, synthesizing it, searching for patterns, discovering what is important and what to be learned, and deciding what you will tell others". Qualitative researchers tend to use inductive analysis of data, meaning that the themes emerge out of the data [28]. There were 2 processes of data analysis: observation and interview. Careful analysis of each method in relation to other methods and also in relation to the research questions enhanced validity and conformability [29].

\subsection{Analysis of Observation Data}

After data collection the following sequential steps, organizing, transcribing, translating, summarizing, and interpreting assisted with data analysis.

\section{Results and Discussion}

\subsection{Teacher's participation in the research process (during teaching and learning observation)}

Teacher and children have a right to be accurately informed in aspects of the research process and their participation can enhance the quality of the research $[30,31]$. For researchers of the human condition and more specifically for those undertaking research in educational institutions, there are ethical dilemmas to negotiate. While one seeks provide adequate information to enable agreement to participate, and not to actively mislead research participants, sometimes to provide them with too much information can work in such a way as to corrupt the research process or influence the research findings.

Thus in this research, the project 'learning through play' may well sensitize teachers to their own teaching practice, and increase the risk that they may consciously or unconsciously, change aspects of that practice while the researcher is in their classrooms. Thus, research of people in their contexts runs some risk of 'steering' 
results or outcomes in particular directions. In this research, the methodology of spending considerable observational time in each teacher's classrooms (not just for example, an hour or so) was a strategy oriented to offsetting this risk. In so doing, I was seeking to observe in as naturalistic classroom settings as possible.

By providing participants with sufficient information about the project, but not the detailed nature and objectives of the research project, I was able to satisfy myself that I was proceeding within the ethical guidelines of the university, and those of the Ministry of Education, and so minimize the potential for the research project to influence the outcomes. Thus informed consent in this project is to be premised on:

1. sound participant understandings of the research process

2. teacher expectation that they should seek not to vary their usual routines and practices and that teaching and learning process should be natural and genuine

3. that teachers, parents and administrators be left in a position to be able to make informed decisions to whether or not to become involved/participate and the ability to do this develops over time.

4. that all participants be given the opportunity, where feasible to become actively involved in different stages of the research endeavour. This includes feedback to participants following the analysis of the research findings.

As the researcher, my responsibility is to provide whatever assistance is required to ensure successful participation. This can include:

1. the design of an appropriate methodology;

2. the inclusion of children, when appropriate, in key decisionmaking aspects, including ethical issues and the interpretation of results

3. consideration of the use of rewards for participation; however, the risk of inducement needs to be carefully balanced against the wish to provide recompense and/or thanks;

4. dissemination of research findings to teachers and parents in appropriate formats;

5. making every effort to ensure that positive change for children ensue, is an outcome of the research.

\subsection{Results for Preschool 1}

The researcher allocated 15 hours of observations at this preschool (3 hours for 5 days).

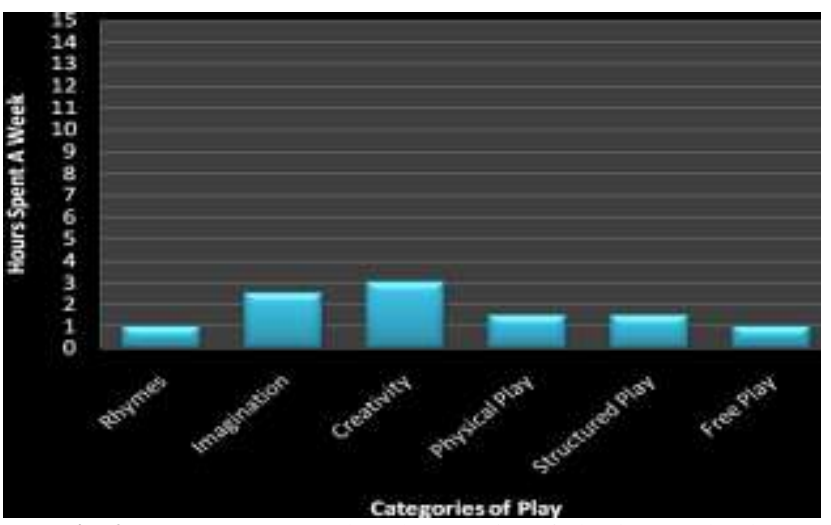

Fig. 2: Hours spent a week and categories of play in Preschool 1

From the 15 hours of observations in Preschool 1, I witnessed 10 $1 / 2$ hours of play activities. The following section provides a breakdown of these observations.

Table 1: Rhymes, chants and riddles

\begin{tabular}{l|l}
\hline Observation Period & Description of Activity and Learning Outcome
\end{tabular}

Half an hour was set These consisted of sessions deployed from the for this type of play. type of "song and movement" which aims to enrich activities for learning English. The teacher uses songs to widen children's vocabularies. It

\begin{tabular}{|l|l|}
\hline & $\begin{array}{l}\text { was observed that the teacher pauses and lets the } \\
\text { children do the singing of well-known songs, for } \\
\text { example "Twinkle Twinkle Little Star". She also } \\
\text { introduced hand gestures and hand play (for } \\
\text { example open and close fingers to show twin- } \\
\text { kling stars) to encourage the children. During the } \\
\text { first-phase the teacher played songs using MP3 } \\
\text { files and the radio, so that the children could hear } \\
\text { the melody and pronunciations. (Observations } \\
\text { and field notes, 10 }\end{array}$ \\
\hline $\begin{array}{l}\text { The August). } \\
\text { tion was a half an } \\
\text { hour session consist- } \\
\text { ing of rhymes and } \\
\text { movement. }\end{array}$ & $\begin{array}{l}\text { This session consisted of rhymes and movement, } \\
\text { and further facilitated by the teacher by linking } \\
\text { the topic and theme of the week - Independence }\end{array}$ \\
$\begin{array}{l}\text { Day. The children were put in two lines, and they } \\
\text { marched and sang the song about Malaysia's } \\
\text { Independence Day - "Merdeka". All of them } \\
\text { including the teacher were holding national flags, } \\
\text { which they had made on the previous day. They } \\
\text { sang the song together and when the phrase of } \\
\text { "Merdeka" arose they raised their hands and the } \\
\text { flags with the word "Merdeka". In this case, play, } \\
\text { movement and song were used to instil in the } \\
\text { children the spirit of independence and a love for } \\
\text { their country. (Observations and field notes, 15 } \\
\text { August). }\end{array}$ \\
\hline
\end{tabular}

Overall one hour was devoted to riddles, chants and rhymes during the observation period. The children's movements, followed the adult's gestures of local and outside cultural traditions as well as national patriotic songs. They use hand gestures to become twinkling stars or patriotic gestures representing love for one's country. They can be employed to support children's literacy and communication skills.

According to [9], gestures and language can be linked to children's play. From a Vygotskian viewpoint, children's symbolic play and movement is understood as a very complex system of communication through gestures that indicates the meaning of playthings. However, in the first situation the teacher used gesture and language more as a drilling approach to develop English vocabularies. This demonstrates a fundamentally behaviourist orientation to teaching and learning. Behaviourist Theory states that learning is a function of overt behaviour expressed by learners in response to certain stimuli. Drilling which uses constant repetition provides practice. Correct performance is then reinforced via the teacher's praise and encouragement.

Table 2: Imaginary Play

\begin{tabular}{|l|l|}
\hline $\begin{array}{l}\text { Observation } \\
\text { Period }\end{array}$ & Description of Activity and Learning Outcome \\
\hline $\begin{array}{l}\text { Half an hour } \\
\text { observation }\end{array}$ & $\begin{array}{l}\left(1^{\text {st }} \text { activity) As a group the children went to the out- }\right. \\
\text { side play area. The children then undertook free play/ } \\
\text { played with pieces of plasticine manipulating it in } \\
\text { their hands and using their own imagination to shape } \\
\text { it. Some children plunged in and tried anything. The } \\
\text { teacher encouraged them, saying- "it is okay to pinch } \\
\text { it, poke it and pound it". Some of them shaped it into } \\
\text { animals such as a cat, or their favorite toys such as } \\
\text { cars, lorries, etc. }\end{array}$ \\
$\begin{array}{l}\text { At the end of the lesson, the teacher showed the chil- } \\
\text { dren how to wipe their fingers with a moist cloth. } \\
\text { Then, the teacher used questions to ask the children } \\
\text { what they made using plasticine. (Observation and } \\
\text { field notes, 14th August) }\end{array}$ \\
$\begin{array}{l}\text { tion observa- } \\
\text { science lesson a }\end{array}$ & $\begin{array}{l}2^{\text {nd }} \text { activity) Another activity in the science lesson } \\
\text { continuation from the previous day were involved the } \\
\text { teacher asking the children to go outside in three } \\
\text { groups of five and collect stones, flowers, dried leaves } \\
\text { and sand for fifteen minutes in a group activity After } \\
\text { each group had found the materials, they gathered the } \\
\text { materials as instructed by the teacher. The teacher } \\
\text { prepared three basins of water, one for each group. }\end{array}$ \\
$\begin{array}{l}\text { The children were asked to put the materials they } \\
\text { found in the water after they were asked to predict } \\
\text { whether each would float or sink. Following this, the } \\
\text { teacher asked the children to test their predictions and } \\
\text { then classify the objects according to whether they } \\
\text { sank or floated. }\end{array}$ \\
\hline
\end{tabular}




\begin{tabular}{|l|l|}
\hline 1 hour observa- & $\begin{array}{l}\text { In this activity, the children worked on two factors: } \\
\text { density and buoyancy. (Observations and field notes } \\
15^{\text {th. }} \text { August) }\end{array}$ \\
\hline tion & $\begin{array}{l}\left(3^{\text {rd }} \text { activity) Another activity I observed that lasted for }\right. \\
\text { thirty minutes was a role-play consisting of the game, } \\
\text { hen and the fox. The children were divided into } \\
\text { groups of three and these groups were scattered } \\
\text { around the playground. The children formed a "fence" } \\
\text { by facing each other and joining hands. One of the } \\
\text { boys was the fox and stood outside the fence. One of } \\
\text { the girls was the hen and stayed inside the fence. The } \\
\text { fox started the game by chasing the hen around and } \\
\text { around in and out of each group. The "fence" tried to } \\
\text { protect the hen from the fox. When the hen grew tired } \\
\text { she was caught by the fox, and then they changed } \\
\text { places. (Observations and field notes, 17 }\end{array}$ \\
\hline
\end{tabular}

Of the more than 15 hours of observation conducted in this preschool classroom, about 2.5 hours of imaginary play were observed. This imaginary play was noted as 'play in passing' during a formal learning session except for the third situation. In the first and second situations the children used plasticine to make, shape and connect things and tested the buoyancy of items from their environment. The objective appeared to be the development of technical skills through play. Children were able to assimilate everyday language with scientific concepts [32]. This kind of play allows children to construct with materials ranging from plasticine to readymade toys.

In the third situation of the hen and the fox game, a child who is acting as a hen must rely on others, the fence, to protect her from the fox. Players acting as the fence indirectly push each child to stay within the social rules of the game, playing as the roles and plot demand. This game is all about teamwork and children understanding that we each need to rely on one another to succeed. This episode is a strong example of the value of play, which according to [32] demonstrates the leading edge of development and creates a zone of proximal development for the child.

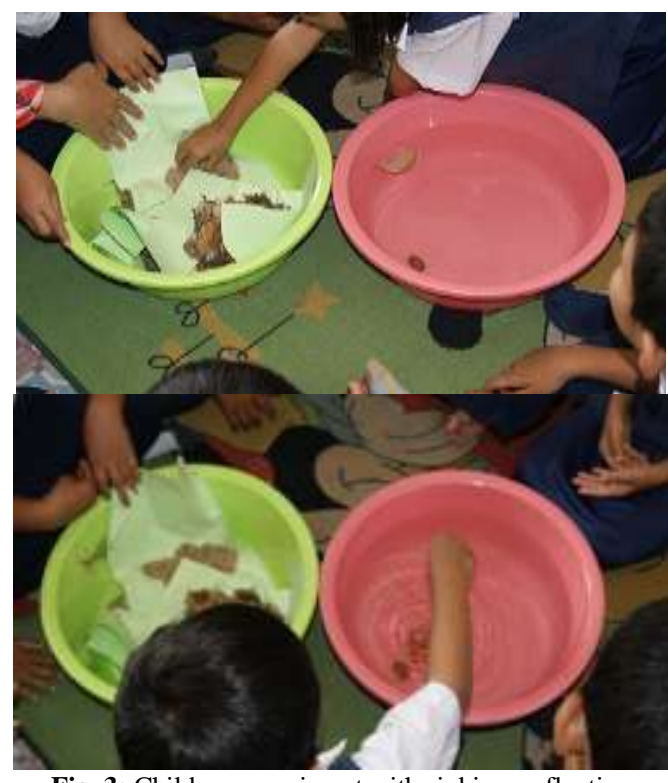

Fig. 3: Children experiment with sinking or floating

Table 3: Creative/ Scientific Play

\begin{tabular}{|l|l|}
\hline Observation Period & Description of Activity and Learning Outcome \\
\hline $\begin{array}{l}1 \text { hour's observa- } \\
\text { tion during an art }\end{array}$ & $\begin{array}{l}\text { The children made a collage with images of flowers } \\
\text { using different types of flowers and colors as well } \\
\text { as colored papers and cardboard, scissors and glue. } \\
\text { Teachers led and facilitated the play during this }\end{array}$ \\
& $\begin{array}{l}\text { session and the children experimented and per- } \\
\text { formed the required task. The collages made by the } \\
\text { children. The children were able to express their } \\
\text { feelings when the teacher asked them about their } \\
\text { opinions of the types, colour, smell, and texture of } \\
\text { flowers. The teacher helped the children by discuss- } \\
\text { ing and expressing their opinion about the topic }\end{array}$ \\
\hline
\end{tabular}

\begin{tabular}{|c|c|}
\hline & (Observation and field notes, $17^{\text {th }}$ August). \\
\hline $\begin{array}{l}1 \text { hour's observa- } \\
\text { tion during a sci- } \\
\text { ence lesson. }\end{array}$ & $\begin{array}{l}\text { On another occasion, the teacher sat with the chil- } \\
\text { dren around two basins filled with water. She had } \\
\text { organized materials such as stones, sand, and dried } \\
\text { leaves for the children to float and sink (classifying } \\
\text { the materials in their experiment). Before this the } \\
\text { teacher explained to them about what they were } \\
\text { going to learn and they played together outside the } \\
\text { classroom in the sand, digging and finding the } \\
\text { materials needed. This continued for a } 40 \text { minute- } \\
\text { session for two days. On one occasion, I asked the } \\
\text { teacher what sort of scientific insights the children } \\
\text { were learning and she explained, "what floats" and } \\
\text { "what sinks". She then elaborated on the complexi- } \\
\text { ty of the science associated with floating and sink- } \\
\text { ing and learning about force, density, gravity and } \\
\text { water displacement. (Observations and field notes, } \\
14^{\text {th }} \text { August). }\end{array}$ \\
\hline $\begin{array}{l}1 \text { hour's observa- } \\
\text { tion as an enrich- } \\
\text { ment and continua- } \\
\text { tion activity of the } \\
\text { science lesson. }\end{array}$ & $\begin{array}{l}\text { This part show what the children produced when } \\
\text { engaging in a creativity activity. In the first figure, } \\
\text { the children used their creativity by arranging and } \\
\text { pasting dried leaves, using materials around them to } \\
\text { draw and make a tree. (Observations and field } \\
\text { notes, } 15^{\text {th }} \text { August). }\end{array}$ \\
\hline
\end{tabular}

Creative play activities appeared to be the children's favourite activities organised by the teachers in this preschool. During a week of observation 'creative play' was observed to account for around 40 to 45 minutes per day or about 3 hours each week. The above situations show how children can actively learn skills and symbolic processing through their interaction with an adult mentor (teacher).

Such activity promotes the development of knowledge and cognitive tools through what the adult provides for them [33]. The idea of children learning to collect materials and create things from them is exciting for children, especially when these materials are around them in everyday life. These constructive skills and strategies contribute to the formation of creative intelligence. Vygotsky's theory places emphasis on children linking with their immediate culture, such as speech and writing and drawing for example. For Vygotsky the internalization process through practice is what contributes to higher thinking skills.

Table 4: Physical Play

\begin{tabular}{|l|l|}
\hline Observation Period & Description of Activity and Learning Outcome \\
\hline $\begin{array}{l}30 \text { minutes observation } \\
\text { of the physical activity } \\
\text { session. }\end{array}$ & $\begin{array}{l}\text { The children were observed chasing and run- } \\
\text { ning in two groups of eight to ten. (Observa- } \\
\text { tion and field notes, } 16^{\text {th }} \text { August). }\end{array}$ \\
\hline $\begin{array}{l}\text { 1-hour observation of } \\
\text { the physical activity } \\
\text { session. }\end{array}$ & $\begin{array}{l}\text { On another occasion, the children were en- } \\
\text { gaged in skipping and hopping together and } \\
\text { this activity was observed and monitored by } \\
\text { the teacher. (Observation and field notes, 18th } \\
\text { August). }\end{array}$ \\
\hline
\end{tabular}

The preschool teacher allocated physical play for about 90 minutes a week. On this theme, Vygotsky theorized "two types of psychological functioning: "natural," consisting of biological growth, both physical and cognitive development; and "cultural," consisting of learning to use psychological and cultural tools, including signs, symbols, and language". This enables us to consider natural and cultural functioning as acting together in a mutually facilitative and integrated process. According to [34] Vygotsky saw development and learning as acting together to create higher psychological functioning.

Table 5: Structured Play

\begin{tabular}{l|l} 
Observation & Description of Activity and Learning Outcome
\end{tabular}

Period 


\begin{tabular}{|l|l|}
\hline $\begin{array}{l}\text { 1 hour of obser- } \\
\text { vation during } \\
\text { Bahasa Malaysia } \\
\text { lesson. }\end{array}$ & $\begin{array}{l}\text { The children played "Fish Me Up" monitored and } \\
\text { facilitated by the teacher. The teacher prepared the } \\
\text { play equipment consisting of alphabet cards with } \\
\text { paper clips on the cards, paper plates, and fishing rods } \\
\text { with magnets. The children were divided into two } \\
\text { teams; each team had a fishing rod. The children } \\
\text { formed a straight line. A plate with "alphabet cards" } \\
\text { representing fish was placed on the finish line. On the } \\
\text { word "go", one child from each team used the fishing } \\
\text { rod to place their fish on the plate and bring back the } \\
\text { "fish" cards, using the magnetic fishing rods to fish } \\
\text { for cards, each with a printed syllable on it and a } \\
\text { paper clip attached. The children had to fish for two } \\
\text { cards to form a word from the cards. They then } \\
\text { spelled the word and read the word aloud. As soon as } \\
\text { they did this, they raced back to their team and hand- } \\
\text { ed the phrases to the next player in the line. They } \\
\text { played in the playground area on this activity for } \\
\text { about sixty minutes. (Observation and field notes } 16^{\text {th }} \\
\text { August). }\end{array}$ \\
\hline $\begin{array}{l}\text { Half an hour } \\
\text { observation } \\
\text { during a mathe- } \\
\text { matics lesson. }\end{array}$ & $\begin{array}{l}\text { During a mathematics lesson, the children were ob- } \\
\text { served in groups of four playing with colored toys in } \\
\text { the shape of beetles for counting practice as instructed } \\
\text { by their teacher. The children were then given a work } \\
\text { sheet to draw and differentiate the beetles' colour. } \\
\text { This play activity finished after thirty minutes of } \\
\text { observation. (Observation and field notes, 14 } \\
\text { gust) Au- }\end{array}$ \\
\hline
\end{tabular}

Early literacy experiences were considered to be very important to Vygotsky, who claimed that the varied sources of writing in children's early years such as drawing provide strong preparation for literacy. Furthermore, in any socio-cultural environment, children need to work together to frame and advance their learning, teaching each other, so to speak. Encouraging classroom collaboration when engaging in difficult problem-solving tasks (for example knowing the alphabet cards and completing a work sheet) will support those child learners who are struggling with the material By interacting with more capable children who continue to mediate transactions between the struggling children and the content, all are more likely to benefit.

Structured play is significant with rules and regulations. In [32] considered it is as an exercise in self-control, whereby the child voluntarily submits to the rules towards achieving the satisfaction of coordination with others.

Table 6: Free Play

\begin{tabular}{|l|l|}
\hline Observation Period & $\begin{array}{l}\text { Description of Activity and Learning Out- } \\
\text { come }\end{array}$ \\
\hline $\begin{array}{l}\text { On two of the five days } \\
\text { under observation, there }\end{array}$ & $\begin{array}{l}\text { The children engaged parallel play and six } \\
\text { children played in a group with toys that were } \\
\text { avare thirty minutes of } \\
\text { free play in each session } \\
\text { during free time (finishes } \\
\text { work). }\end{array}$ \\
$\begin{array}{l}\text { very busy baking play dough. The girls } \\
\text { shared recipes with each other and come up } \\
\text { with some very creative cupcakes to celebrate } \\
\text { birthdays. (Observation and field notes on } \\
14^{\text {th }} \text { and } 16^{\text {th }} \text { August). }\end{array}$ \\
\hline
\end{tabular}

Freeplay experiences that children choose for themselves and that involve minimal adult intervention. All play experiences are structured to a greater or lesser extent by the resources available, the people involved and the context. In [35] suggests that children can demonstrate high order problem solving in highly creative ways during free play. From the observation, we can say that the children want to be seen by teachers and particularly by peers with whom they seek to develop friendship networks. They also want to share tools and equipment with others and to do things together.

\section{Conclusion}

In considering play through a sociocultural lens we are provided with new ideas about how different categories of play can be used in preschool curriculum development and in improving practice and policy. It is this sociocultural lens that provided new insights into how to build on current Malaysian preschool policy and practice across a range of agencies. The model is highlighted here as maintaining a sociocultural theoretical lens is vital in enabling us to recognise the importance of an inclusive context. It is also vital in directing future research and curriculum development, aimed at improving practice and policy.

In recognising that play is a major component in a child's social, cognitive and physical development we must understand the position of play within the dynamics of early childhood education. The pedagogical orientation uses the cycle of planning the play/learning environment, interacting with children in a range of activities, observing, reflecting, evaluating and returning to further planning. The aim is to ensure a flow of information about children's play and learning from two pedagogical zones - adult-and child-initiated activities, both of which have contrasting but complementary forms of adult and child involvement, co-constructive engagement, and pedagogical strategies.

Having a sociocultural framework enables the researcher to structure data collection in a way that focuses on the elements of practice that enable or restrict opportunities to learn through play, and to interpret data from a vantage point specifically designed to interpret these actions and consequences. Indeed, the provision of research evidence where theory supports pedagogy provides secure justification of the benefits of building play-based curriculum. In starting at the top and working down we find that the MOE in Malaysia include discussion on the benefits of learning through play. However, they do not provide clear guidelines on when and how to use it. From the data presented here one of the strongest findings relates to a need for administrators and teachers to have specific training in current education theory and method, and for teachers in particular to be involved in ongoing and focused professional development. Indeed, it is important to note that the findings from this study, demonstrate how western type practices can operate in classrooms that have a non-western culture, where daily life is governed by cultural and traditional values.

This demonstration, which is provided via a sociocultural lens on classroom practices, is a direct effort to demonstrate to all stakeholders in the preschool education sector what current research can offer in terms of providing quality play based learning opportunities. The outcomes demonstrate how the theory behind learning through play supports practices that can be integrated into classrooms without impacting on time and without inhibiting curriculum content. An outcome for the MOE therefore is that by providing new insights into ways to incorporate learning through play approaches into the curriculum they can influence educators to further value current educational methods and practices.

\section{Acknowledgement}

The authors would like to thank the Research Management, Innovation and Commercialization Centre, Universiti Sultan Zainal Abidin, Terengganu, Malaysia for providing the financial assistance to support the publication fee of this article.

\section{References}

[1] Rogoff, B. (2003). The cultural nature of human development. Oxford University Press.

[2] Bruner, J. (1986). Actual Minds: Possible Worlds. Harvard University Press

[3] Wenger, E. (1998). Communities of practice: Learning, meaning and identity. Cambridge University Press.

[4] Hedges, H. (2000). Teaching in early childhood: Time to merge constructivist views so learning through play equals teaching through play. Australian Journal of Early Childhood, 25, 16-21.

[5] Rogoff, B. (1990). Apprenticeship in Thinking: Cognitive Development in Social Context. Oxford University Press.

[6] Brennan, C. (2008). Partners in play: How children organize their participation in sociodramatic play. $\mathrm{PhD}$ thesis, Dublin Institute of Technology.

[7] Rogoff, B. (1994). Developing understanding of the idea of communities of learners. Mind, Culture and Activity, 1(4), 209-229. 
[8] Wertsch, J. V. (1991). Voices of the mind: A sociocultural approach to mediated action. Harvard University Press.

[9] Vygotsky, L. (1978). Mind in society. Harvard University Press

[10] Nicolopoulou, A. (1993). Play, cognitive development and the social world; Piaget, Vygotsky and beyond. Human Development, $36,1-23$

[11] Cole, M. (1996). Cultural psychology: A once and future discipline. Harvard University Press.

[12] Broadhead, P. (2006). Developing an understanding of young children's learning through play: The place of observation, interaction and reflection. British Educational Research Journal, 32(2), 191-207.

[13] Wood, E. (2010). Developing integrated pedagogical approaches to play and learning. In P. Broadhead, J. Howard, \& E. Wood (Eds.), Play and Learning in the Early Years. California: Sage Publications, pp. 9-25.

[14] Edwards, S. \& Brooker, E. (2010). Rethinking play. Open University Press.

[15] Edwards, S. (2007). From developmental-constructivism to sociocultural theory and practice: An expansive analysis of teachers' professional learning in early childhood education. Journal of Early Childhood Research, 5(1), 83-106.

[16] Wertsch, J. V. (1991). Voices of the mind: A sociocultural approach to mediated action. Harvard University Press.

[17] Wood, D. J., Bruner, J. S. \& Ross, G. (1976). The role of tutoring in problem-solving. Journal of Child Psychology and Psychiatry, 17, 89-100.

[18] Wood, R. E. (1986). Task complexity: Definition of the construct. Organisational Behavior and Human Decision Processes, 37, 60-82.

[19] Rogoff, B. (2003). The cultural nature of human development. Oxford University Press.

[20] Moran, S. \& John-Steiner, V. (2003). Creativity in the making. In R. K. Sawyer, V. John-Steiner, S. Moran, R. J. Sternber, D. H. Feldman, \& J. Nakamura, (Eds.), Creativity and Development. New York: Oxford University Press, pp. 61-90.

[21] Md. Jaafar, F. (2011). Kepentingan aktiviti bermain di dalam pendidikan prasekolah. Malaysian Educators Deans' Council Journal, 3, 1-8.

[22] Sharifah, N. P. \& Aliza, A. (2011). Pendekatan bermain dalam pengajaran bahasa dan literasi bagi pendidikan prasekolah. Jurnal Pendidikan Bahasa Melayu, 1(2) 1-15.

[23] Morrison, G. S. (2009). Early Childhood Education Today. Pearson International Edition.

[24] Smith P. K. \& Pellegrini, A. D. (2008). Learning through play. In R E. Tremblay, R. G. Barr, R. DeV. Peters \& M. Boivin (Eds.) Encyclopedia on Early Childhood Development. Centre of Excellence for Early Childhood Development. http://www.childrencyclopedia.com/documents/SmithPellegriniAN G.

[25] Chancellor, B. (2005). The changing face of play in Australian primary school playgrounds. $\mathrm{PhD}$ thesis, RMIT University.

[26] Hamzah, D. (1994). Pola-pola permainan dan pengurusan aktiviti permainan di pusat pendidikan kanak-kanak prasekolah. Master thesis, Universiti Kebangsaan Malaysia.

[27] Bogdan, R. C. \& Biklen, S. K. (1982). Qualitative research for education: An introduction to theory and methods. Allyn and Bacon.

[28] Patton, M. Q. (1990). Qualitative evaluation and research methods. Sage Publications.

[29] Brewer, J. \& Hunter, A. (1989). Multimethod Research. A Synthesis of Styles. Sage Publications.

[30] Semmens, A. (2004). Schools of the Future: School community perceptions. PhD thesis, RMIT University.

[31] Wenger, E. (1998). Communities of practice: Learning, meaning and identity. Cambridge University Press.

[32] Vygotsky, L. (1976). Play and its role in the mental development of the child. In J. Bruner, A. Jolly, \& K. Sylva (Eds.), Play: Its Role in Development and Evolution. New York: Basic Books, pp. 537-554.

[33] Vygotsky, L. (1932). Thought and language. MIT Press.

[34] Berk, L. \& Winsler, A. (1995). Scaffolding children's learning: Vygotsky and Early Childhood Education. National Association for the Education of Young Children.

[35] Bruce, T. (2001). Learning through play: Babies, toddlers and the foundation years. Hodder Education. 